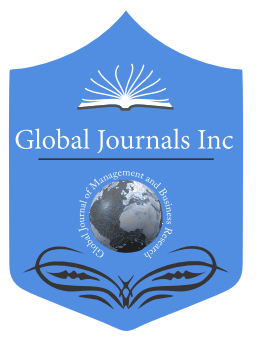

GLOBAl JOURNAL OF MANAGEMENT AND BUSINESS RESEARCH: A ADMINISTRATION AND MANAGEMENT

Volume 20 Issue 10 Version 1.0 Year 2020

Type: Double Blind Peer Reviewed International Research Journal

\title{
Role of Effective Corporate Governance and Motivational Leadership in Increasing Productivity and Efficiency of Human Resources
}

\author{
By Mohammad Mahfuzul Islam Chowdhury, Khatijah Binti Othman, \\ Mohammad Aktaruzzaman Khan \& Ibrahim Fahad Sulaiman
}

Abstract- Workforce motivation is a concern for the corporate sector. Corporate governance and leaders have a significant role in motivating human resources to increase their productivity and efficiency. This study aims at identifying the impact of effective corporate governance and motivational leadership factors on the productivity and efficiency of human resources. The authors, in this paper, critically discussed determining human resources, elements of effective corporate governance, features of ideal corporate leader, and motivational leadership factors that influence the workforce in organizations. This study is descriptive and conceptual, and used secondary data obtained from different books, journals, and research articles (both theoretical and empirical) in the related field.

Keywords: corporate governance, efficiency, human resources, motivational leadership, motivational factors, productivity.

GJMBR-A Classification: JEL Code: 015

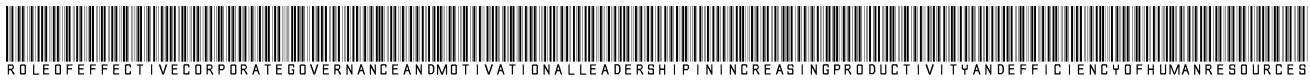

Strictly as per the compliance and regulations of:

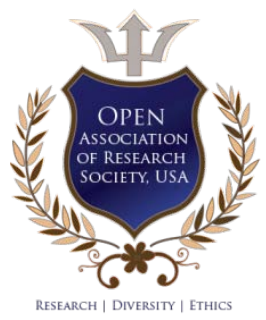

(C) 2020. Mohammad Mahfuzul Islam Chowdhury, Khatijah Binti Othman, Mohammad Aktaruzzaman Khan \& Ibrahim Fahad Sulaiman. This is a research/review paper, distributed under the terms of the Creative Commons Attribution-Noncommercial 3.0 Unported License http://creativecommons.org/licenses/by-nc/3.0/), permitting all non-commercial use, distribution, and reproduction in any medium, provided the original work is properly cited. 


\title{
Role of Effective Corporate Governance and Motivational Leadership in Increasing Productivity and Efficiency of Human Resources
}

\author{
Mohammad Mahfuzul Islam Chowdhury ${ }^{\alpha}$, Khatijah Binti Othman ${ }^{\circ}$, Mohammad Aktaruzzaman $\operatorname{Khan}^{\circ}$ \\ \& Ibrahim Fahad Sulaiman ${ }^{\omega}$
}

\begin{abstract}
Workforce motivation is a concern for the corporate sector. Corporate governance and leaders have a significant role in motivating human resources to increase their productivity and efficiency. This study aims at identifying the impact of effective corporate governance and motivational leadership factors on the productivity and efficiency of human resources. The authors, in this paper, critically discussed determining human resources, elements of effective corporate governance, features of ideal corporate leader, and motivational leadership factors that influence the workforce in organizations. This study is descriptive and conceptual, and used secondary data obtained from different books, journals, and research articles (both theoretical and empirical) in the related field. After a thorough analysis of secondary materials, the authors identified several salient motivational factors and components for effective corporate governance; that directly influence human resources in increasing their productivity and efficiency. Organizations can use the findings of this study to ensure effective corporate governance and to motivate human resources in increasing their productivity and competence to cope with the changes and meet the challenges of the corporate sector.
\end{abstract}

Keywords: corporate governance, efficiency, human resources, motivational leadership, motivational factors, productivity.

\section{INTRODUCTION}

$t$ is essential for managers to attract, motivate, and retain employees (Mrudula, 2006). Employees' attraction, motivation and retention are most fundamental for increasing their efficiency and productivity as well as for the organization. Motivating human resources is a challenging, critical, and sensitive task for managers in the corporate sector. Employees' commitment and loyalty toward their employers are diminishing in today's competitive corporate world because of some reason. Lack of proper motivation is one of the reasons. Executive managers perform as leaders in the corporate sector. On the other side, employers are a central part of corporate governance. There must have a joint effort of executive leaders and

Author $\alpha$ : PhD Researcher, Faculty of Leadership and Management, Universiti Sains Islam Malaysia (USIM), Malaysia.

e-mail:mahfuzichy@gmail.com

Author $\sigma$ W: Universiti Sains Islam Malaysia (USIM), Malaysia.

Author p: International Islamic University Chittagong (IIUC), Bangladesh. corporate governance in motivating human resources. Managers' duty not only focuses on implementation and handling the complication of ongoing tasks in their respective organizations but also to uphold their responsibilities for advancement and preparing the organizations for the future. Side by side, they must be an effective change agents and deal with overcoming resistance to change. A manager's goal must be to help create a truly "motivating organization," one that inspires each employee to do his or her very best every day, particularly when the manager is not looking (Bruce, 2006). Corporate leaders accomplish their tasks in organizations with their loyal workforce. Without skilled and committed workforce, they are not able to meet the objectives of the organizations. The productive and efficient workforce is helpful in this regard. Corporate executives ought to know how to accomplish their tasks fruitfully according to the increased productivity of their workforce, as people in the workplace is salient part of the advancement of the organization. Without the positive motivation of the workforce, it is impossible to meet the objectives and cope with the changes in the competitive corporate sector. People who work in the organization are different in attitudes, skills, and manners. In such a diverse workforce, ideal managers work tactfully and influence their human resources for ensuring proper outcomes from them. On the other hand, good governance is a more discussed issue in the corporate sector. Beside corporate leaders, there is a vital role of corporate governance to motivate people in the workplace to increase productivity and efficiency. For effective corporate governance, there must have some salient features. Shortage of these features, corporate governance never motivate the workforce effectively. To establish unity in diversity among the human resources in achieving organizational goals is not an easy task. Corporate leaders, as well as corporate governance, are to do this difficult task comprehensively with innovative strategy. As a whole, an organization needs a motivated and productive workforce to be a productive organization. Joint efforts of motivational leadership and effective corporate governance ensure a motivated workforce in an organization in meeting organizational goals. To 
determine motivational corporate leader, we ought to differentiate political leader and corporate leader considering their responsibilities and tasks. The concept and establishment of motivational corporate leadership, in some cases, is neglected. We have to eradicate this negligence to get a motivated workforce. Corporate governance and leadership in the corporate sector should consider several salient motivational factors to influence human resources in increasing productivity and efficiency. In this study, the authors try to focus on the elements of effective corporate governance, characteristics of motivational leadership, and salient factors of human resource motivation. Through ample literature review, the authors determined that amalgam of effective corporate governance, motivational leadership, and motivational factors can ensure and increase efficiency and productivity of human resources that meet organizational goals.

\section{Objectives}

In this study, the authors emphasized the recognition of salient factors of human resource motivation in increasing productivity and efficiency in them with the amalgam of elements of effective corporate governance and motivational leadership factors. The justification of this study is that no such inclusive research is done to focus on the joint efforts of effective corporate governance and motivational leadership to motivate the workforce in organizations. Several scholars did separate studies on employee motivation, corporate governance, and leadership. Related to the main objective, the authors determined the number of other goals in this study; these are as follows:

- To focus on the concept of human resource and human resource management.

- To focus on the concept of corporate governance.

- To identify the salient elements of effective corporate governance.

- To focus on the concept of leadership, management, and leadership character.

- To focus on the concept of motivation and human resource motivation.

- To identify the salient factors of human resource motivation.

\section{Methodology}

This study is library-based research, and in this research, the authors used secondary materials. The researchers studied available published literature, journals, articles, magazines in this related field to determine elements of effective corporate governance, identify exclusivity of motivational corporate leader as well as develop salient factors of human resource motivation in increasing productivity and efficiency in the workforce. This research is structured and accomplished according to the research objective and goals.

\section{Human Resource \& Human Resource Management}

There is no existence of an organization without human resources; it may be a profit or not for profit organization. Organizations achieve their goals by proper use of their workforce under the supervision of corporate leaders within a structured human resource management system.

\section{a) Human resource}

The term "human resources" can refer to the company's employees, who are one element of the resources available to organizations, sitting alongside financial and other assets that facilitate the attainment of business goals (Gilmore, 2009a). Some people do not agree to consider humans as resources a resource like other resources such as financial resources, technological resources, natural resource, or environmental resources. They think that human is not a machine or material asset and cannot be a resource. However, in short, we can say, human works in organization for attaining organization goals as well as personal achievement is called human resource. Every human cannot be considered as human resources, such as a beggar however, he/she is a human, as he/she is not involved in an organization to meet objectives of the organization and has no personal attainment from the organization. Human resources must work in an organization under the set rules of the management and committed to working for attaining organizational goals.

\section{b) Human resource management}

There is no one accepted definition of human resource management, and several definitions are there. Personnel management was the previous term for human resource management. Boxall, Purcell, and Wright (2007) defined human resource management (HRM), the management of work and people towards desired ends, is a fundamental activity in any organization in which human begins are employed. If we see the companies in the UK, not all organizations in the country use the term "human resources" to describe the people management function. Some organizations still choose to use the previous words "personnel" or "personnel management." The history of personnel management's role is prolonged. It emerged at the end of the nineteenth century. The latest term human resource management, instead of personnel management, arrived in the UK in the 1980s. Whatever we say, personnel management or human resource management, the role of both is to manage people and deal with the people in the organization. Furthermore, it 
deals with recruiting and selecting staff in an organization, developing human resources, administering performance, rewarding people at work, ensuring health safety, and employee well-being. It also deals with equality, diversity, grievance, discipline, and dignity at work. It engages a wide range of activities and issues, with responsibility for their performance lying with different people. Human resource management also has a vital role in developing policies and procedures related to the workforce of the organization. But making these policies and procedures, in many cases, lies with others. It means that human resource management is not only the sole authority of working people in an organization. Accordingly, it does not always have control over its area. Extensively it manages and controls the workforce with the collaboration of other operational bodies of the organization. In this regard, human resource management works as a bridge between corporate governance and workforce and keeps close working relationships among all functioning units of the organization.

Boxall et al. (2007) studied that HRM is an inevitable consequence of starting and growing an organization. While there is a myriad of variations in the ideologies, styles, and managerial resources engaged. The functions of HRM are to monitor and oversee the people in the organization, and it ensures implementation of the human resource policies. At this juncture, policies are the pronouncements of principles intended to be informed by strategy and to guide practice. They can clarify situations, reduce dependence on individuals, produce consistent behavior, and help employees and managers to know where they stand. Some organizations hold a gap between human resource policy and practice. This gap has a direct impact on people in the workplace. Traditionally, much human resource management work has been about developing policies to do with recruitment, selection, promotion, and appraisal. A common problem to human resource management functions is the failure to evaluate or monitor policies. Unless policies are monitored and evaluated against concrete objectives, no one will know whether or not objectives are being met or whether a gap between policy and practice exists (Newell \& Scarbrough, 2002). Aspects of human resource motivation should properly be included in human resource management policy so that it can be ensured productivity and efficiency of human resources to attain organizational goals. In making such a policy, there is a vital role in effective corporate governance as well as motivational corporate leadership.

\section{Effective Corporate Governance}

Before going to discuss corporate governance, we need to identify what is meant by governance. From the Cambridge English Dictionary (2019), we find the definition of governance that "the way that organizations or countries are managed at the highest level."Governance associates to government and the root word govern means to control. Corporate governance means the system of rules, practices, and processes by which a company is directed and controlled. The purpose of corporate governance is more associated with the dictionary definition. Governance principles dictate the company objectives should be met the organizational processes and should be executed effectively, not neglected, skirted, or altered for the benefit of individuals (Weill \& Ross, 2004).

Effective corporate governance composed of several salient features. These traits are functional and directly related to the effectiveness of corporate governance.

\section{a) Board of directors}

It is a vital part of effective corporate governance. Governance board of an organization should have highly skilled directors, with principled personality and extensive business knowledge. The board of directors oversees and controls the functions of top corporate leaders, as they are the operational leaders in the organization. Side by side, the board, also monitors the overall activities of the organization. In this connection, the top-level executives are just one level below the board of directors. So, the intensive relationship between board of directors and executives is very much crucial for good governance. The effectiveness of an organization's governance system is the ethics and attitudes of the directors chosen to serve on the board (Tiller, 2011). An effective and efficient board needs to be composed of professional directors. The professional and ethical mannered directors are resistant that the company's executives or any other people cannot manipulate them personally. Also, such directors do not receive any unfair means and do their level best for the betterment of shareholders as well as stakeholders of the organization.

\section{b) Management configuration}

Another crucial component of corporate governance is the management configuration. It refers to how an organization categorizes its management hierarchy. In this configuration, the top corporate executives carry out their tasks for overseeing all activities of the company and ensure that they are accountable for all decisions they take on behalf of the company. Tiller (2011) quoted the recommendation of Stanford that organizations need a decentralized management configuration with least vertical layers since excessive levels of executives tend to slow down the decision and review process and potentially hide any unlawful activity. By a flatter, less hierarchical layer, decisions, and policies of the organization can be implemented smoothly and within the timeframe. Companies in Sweden, like other egalitarian countries, 
have this type of organization pattern. Prompt execution of decisions is crucial for the productivity and efficiency of the organization. Management structure with minimal vertical layers can ensure on-time execution of decisions taken by the respective authority.

\section{c) Shareholders}

Shareholders are a fundamental part of corporate governance. By definition, shareholders are owners of the company limited by shares, and they form the board of directors. There is a vital role of shareholders in various issues of the company. The shareholders themselves must be able to vote independently for different aspects of executive appointments, financial decisions, and other critical issues of the company's future (Tiller, 2011). In organizational perspective, shareholders must be free from any unjustified influence from any side of the organization so that they can be able to vote independently for financial matters and any other concern of the organization. It's corporate executives' duty with full oversight by the board of directors to create a free-fare corporate environment for the shareholders in this regard. Providing constructive opinions freely for the betterment of all stakeholders of the organization, shareholders can keep fruitful contributions to effective corporate governance.

\section{d) Auditors}

Tiller (2011) noted that proper governance dictates all financial actions, decisions, and outlays be audited routinely by a completely independent organization. In this regard, an organization should arrange regular audit by an independent auditor firm for its all financial activities and decisions to ensure transparent and effective corporate governance. The auditor firm should have the authority to thoroughly examine the company's financial record. An organization should establish openness and transparency in all activities for good governance, and independent auditors can ensure this type of corporate environment. Without the scrutiny of all monetary decisions, an organization cannot ensure effective governance and, as a result, will not be a productive one. In this regard, the personal and organizational integrity is a must for a transparent transaction of finance. Organizational integrity largely depends on personal integrity of top-level corporate leaders since they are the mentors of their subordinates. Honesty should be one of the main concerns of an organization to meet the challenges in a changing competitive environment and achieve organizational goals. Organizational integrity is more important than employees' integrity, as integrity motivates the employees, to be honest. The fruitful and regular audit can ensure the overall integrity of the business, and it influences individuals to be productive.
There is a significant role in corporate governance to motivate human resources in increasing and maintaining productivity and efficiency to attain organizational goals. In this regard, the government must be composed of a professional-skilled and ethical board of directors, management configuration, furthermore, it should have proper participation of shareholders, and independent audit of all financial activities on a regular basis. Also, holding aforesaid four elements, effective corporate governance maintains the following affairs accordingly:

- To ensure the rule of law for all individuals,

- To establish transparency and accountability in all levels of management,

- To makeresponsiveness to serve the best wellbeing of stakeholders,

- To set up participatory management involves all management staff in decision making,

- To ensure equity and inclusiveness from top to bottom of the organization.

Effective corporate governance oversees organizational integrity, and such integrity has a direct impact on personal integrity from top-level managers to lowest level workforce. Gandz, Crossan, Seijts, and Reno (2013) explained that corporate directors look or should look for three things in the executives they hire, assess and occasionally have to fire: competencies, commitment and character. These are relevant issues in corporate governance. Competency of individuals in an organization refers to be able to accomplish the task. Commitment means to be devoted to a particular activity or affair. It determines how prepared the workforce is to make the sacrifices necessary to achieve organizational goals. The character of human resources means how individuals use their capabilities, by which they are identified in and out of the organization. Organizational character refers to how decision is shaped and how these decisions are implemented and evaluated in the organization. Competencies, commitment, and character of executives, primarily depend on motivation and organizational integrity. Effective corporate governance is a substantial motivational factor that has a direct impact on human resources to increase their efficiency and productivity; consequently, the organization becomes productive and attains organizational goals.

\section{Leadership, Management and LEADERSHIP CHARACTER IN THE Corporate Sector}

Quality of corporate leadership, management of organization, is important discussed issues in the corporate sector. They are correlated with each other. 


\section{a) Leadership and management}

Robbins and Judge (2011) explained that leadership is the ability to influence a group toward the achievement of a vision or set of goals. The source of this influence may be formal, such as that provided by managerial rank in an organization. Corporate leaders' salient tasks are organizing-monitoring-motivatingcommunicating and developing human resources. On the other hand, they deal with analyzing-appraising and interpreting the performance of their people. In the twenty-first century, the tasks of management and leadership have become more multifaceted. Leadership and management are often confused terms, although they are part and parcel of the organization. Kotter (1999) of the Harvard Business School noted that leadership and management are two distinctive and complementary systems of action. Each has its own function and characteristic activities. Management is about coping with complexity. Leadership, by contrast, is about coping with change.

Many business enterprises failed to increase and ensure organizational productivity, caused by proper leadership, though they had skilled human resources and well-equipped workplace. Corporate leaders in these enterprises could not be able to motivate their people with the implementation of salient factors of workforce motivation. Human resources need persuasion to inspire them to working better for the organization. In this regard, corporate leaders need to be self-motivated first to stimulate others. If they do not feel to do something more for the betterment of their people and organizations, besides their routine tasks, it may not be possible to cope with the existing and upcoming corporate challenges and changes. Organizations need strong corporate leadership and management for optimal effectiveness and meeting organizational goals. Corporate leaders are the authoritative part of management. They must know the gap between policy and practice in the organization to determine an action plan for minimizing this gap. It helps to make the workforce motivated and increase productivity as a whole. Linda A. Hill, a management expert, identifies that there is a general perception; the manager is as boss (Hill, 2003). When asked to describe about a manager, nearly all the managers began by discussing management's rights and privileges, not its duties.

It is a wrong perception of a large number of executives of organizations that to become a manager to exercise power and control over their people. In this connection, they forget that not to exercise power but to motivate their workforce is a crucial part of their corporate leadership in increasing organizational productivity. Considering all aspects of corporate leadership, managers are not only bosses but also they should be effective motivators, change-makers, and well-wishers of their people. It is possible to achieve organizational goals by inspiration of the workforce in the organizations.

Honesty in all levels of management is crucial for an organization. When business executives take decisions between right and wrong, these alternatives are usually easy. On the contrary, at the time of deciding between two options that both seem to be right, it is tough for them to make a decision. Tiller (2011) asserts it is the job of corporate governance to watch over the business process and ensure that business leaders conduct themselves appropriately. Also, he quotes from Colvin that top leaders sometimes abandon their ethics and turn to greed, selfishness, and corruption.

Value centered corporate leadership can ensure integrity at both individual and organizational level, and that is contributing to meet challenges and cope with changes in and out of the organization. This kind of leadership can nurture integrity through a combination of own action and different programs arranged by the organization.

\section{b) Character of leadership}

Effective leadership in the corporate sector largely depends on how many motivational elements of character, a corporate leader holds or does not hold. Leadership is a term with multi-dimensional aspects; it may be a political leadership or corporate leadership, but there is a significant difference between political leaders and corporate leaders. Political leaders also motivate their people as like as corporate leaders; in this regard, they do not have any structured action plan to appraise-analyze and interpret the performance of their followers. On the contrary, business leaders must have a structured action plan to oversee their people. Hence they should have some elements of character that manage their workforce. It needs to learn from where corporate leaders obtain the elements of character. Gandz et al. (2013) studied that some elements, especially personality traits are inherited and rest of these come from early childhood development, education, and experiences in both works related and socially related organizational settings. Furthermore, corporate leaders gain some significant elements of the character directly from their life experiences. Motivational leadership power is one of the parts of personality of an executive to manage their people effectively, and it is fundamental to make the organization dynamic. By these settings, fundamentals of the character of a corporate leader become multidimensional.

\section{Vil. Motivation and Motivational FACTORS InFLUENCING HUMAN Resources}

Every person gets motivated positively or negatively (Mrudula, 2006). Ideal corporate leaders lead 
from the front using different motivational techniques to influence people in an organization to increase their efficiency and productivity. It is needed to define motivation first to discuss motivational factors. In short, "Motivation is the drive of the mental forces to accomplish an action." The dictionary definition of motivation is "having the encouragement to do something."Anne Bruce (2006), a featured presenter for the London Institute of Management, highlighted that managers make every employee feel like a business partner. Because when people feel ownership of something, they feel a strong motivation to look out for it. Corporate leaders ought to influence their people to make them efficient and productive. Successful management largely depends on employee motivation. Motivational team spirit should be ensured by the corporate leaders so that employees can work with strong motivation to be more committed to the organization. But in many cases, a large number of business executives fail to understand practical process of human resource motivation. They also fail to realize that motivation is a critical aspect of corporate leadership. Lack of practical knowledge of motivation, many corporate leaders, cannot handle the unwanted situations in organizations. If they had practical understanding, they would be able to manage and influence their people successfully. Without motivation in the workplace, the business will lack efficiency and productivity.

Motivation and job satisfaction are related with each other. Mrudula (2006) noted that the factors that motivate employees are the same factors that decrease or prevent job satisfaction. For effective motivational procedures and to make sure productivity of the workforce as well as organization, corporate leaders always need to understand the factors that motivate employees successfully. Following motivational factors may be considered to inspire human resources in organizations in ensuring effective corporate governance, productive human resources, and successful organizations:

\section{a) Organizational citizenship feeling}

Corporate leaders should eliminate authoritative manners so that they can build up a friendly work environment in an organization to influence their people in feeling organizational citizenship. Citizenship behaviors lubricate the social machinery of the organization. They provide the flexibility needed to work through many unforeseen contingencies; they enable participants to cope with the otherwise condition of interdependence on each other (Smith, Organ, \& Near, 1983). Corporate Executives should explain the workforce; how they are running the business. When employees know how they fit in and the difference they make, they can do their work more intelligently (Bruce, 2006). By this explanation, employees will be able to know the gap between what they do and what they should do. Employee friendly work environment is crucial for productivity and efficiency that minimizes this gap. Corporate leaders must help the employees feel as if they own the business, and are the citizens of the organization. It is only possible when managers empower their people. In this regard, profit sharing may be a way to make a feeling of ownership. If an organization shares its profit proportionately to the people work in the organization, they will feel them as partners of the organization and will be more committed to work for the betterment of the organization.

\section{b) Innovative and calculated risk-taking}

Bruce (2006) asserts that the only way to get better is to try new things, and organizations that don't innovate stagnate. They may even go out of business. Innovative and calculated risk-taking increases the performance and effectiveness of the workforce as well as business enterprises. Corporate leaders should encourage their people to find out new ways of doing their work, which may be better than the previous one. In some cases, the workforce may make mistakes for taking a risk, though they have done the job sincerely. But they should not be blamed for this mistake. If people blame them, they will not be eager to take a risk for a second time. Business executive should keep in the mind that failure is not a crime. Trying new things may be better for organizations in today's competitive corporate environment. Though there is a chance of making mistakes, the ideal corporate leaders ought to develop a calculated and creative risk-taking mentality in their workforce that will help them to build up their individual as well as organizational performance. Taking a calculated risk, employees become able to learn; how to meet the managerial challenges and cope with the changes in the changed competitive situations. Employees can develop their performance by a taking risk with the help and monitoring of their supervisors. So, corporate leaders should motivate their people to receive creative and calculated risk for meeting organizational goals.

\section{c) Encouragement of becoming an innovative thinker}

Corporate leaders, who encourage creative and innovative thinking among their people, are considered as natural born motivators. In some cases, employees are afraid of thinking creatively, because of their rude supervisors; as a result, their performance turns down or remains unchanged. Here we see no improvement of the performance of employees in this situation. Managers should eliminate their rudeness and should inspire their people for innovative and creative thinking for the betterment of their organizations.

\section{d) Proper assistance in achieving performance \\ Managers should help employees to achieve performance. All employees do not need the same help;}


it depends on their requirements and talent. The job and responsibility of the individual employee should be specified to them, and employees ought to be informed; what the objectives of the organization are. If the corporate leaders co-operate their employees in achieving performance, the employees will be motivated highly and be able to meet the challenges in the changing environment. During helping the employees, managers should keep in their accounts that all employees do not have equal talent in achieving their target. In this regard, John F. Kennedy, former president of the United States, says, "all of us do not have equal talent, but all of us should have an equal opportunity to develop our talent."

\section{e) Reward and appreciation for the performance}

Reward management is one of the motivational activities of human resource management. Corporate leaders ought to ensure rewards for their workforce for better performance. Eerde (2015) explained that a reward system consists of the policies and mechanism by which organizations administer employee rewards, for example, by annual pay increases. This method has a powerful influence on the recruitment and retention of employees. Performance-based reward motivates employees, and it increases productivity and efficiency. People at work want remuneration and appreciation. In this regard, the reward system must be well structured and free from any unfairness. If managers fail to establish fairness in rewarding employees, it will not motivate them in increasing productivity; as a result, they will not feel committed to their tasks. In the case of appreciation for better work, money is not always a matter. In some cases, corporate leaders can appreciate the work of someone by sending an e-mail or memo to others publicly, recognizing the good work of that person (Bruce, 2006), and it influences the employee to uphold his/her performance in the future. Pilbeam (2009:170) describes three strategic approaches in the reward system. These are employer perspective involves achieving a reward strategy that fosters the knowledge, competence, and behaviors necessary for business success, the employee perspective ensures that the reward strategy is attractive. The cost perspective has to make sure the reward strategy is affordable and sustainable. He also emphasizes the need to balance these three perspectives. Corporate leaders should consider these perspectives to form a structured reward system in organizations.

\section{f) Incentives for workforce}

Employees want an entrepreneurial environment, skill development, and opportunities for growth and competitive compensation to be motivated (Harunavamwe \& Kanengoni, 2013). An organization can offer different motivational incentives to their workforce in increasing their efficiency and productivity.
Organizations can design their employee incentives for the higher performance levels. In this connection, corporate leaders have a vital role in establishing a structure of incentive scheme with their creative and innovative skills, considering the mentality and needs of their employees; and organizational settings.

\section{g) Empowerment of workforce}

Empowerment is a core concept of the new management model by which the organization harnesses individual talents to the fullest (Chebolu, 2006:60). Corporate leaders should give authority to their workforce in accomplishing everyday jobs so that the employees become powerful in doing their tasks freely. This kind of empowerment increases its capability. But it is tough for managers to do so and many managers are resistant to do this, and they like to hold all the power on their own. But smart managers release the authority within their every employee so that the employee can do the work his/her level best. If an employee gets power, it means that he/she takes the authority and responsibility to do his/her job efficiently and effectively. Consequently, feeling of accountability grows in the employee's mind. Empowerment makes the workforce motivated. It ensures job satisfaction and employees become happier to work with the organization.

\section{h) Pleasurable workplace}

There is a misperception among many managers that fun doesn't belong at work. But in the workplace, fun is needed to motivate the workforce. Fun on the job and employee productivity, creativity, morale, employment satisfaction, and retention are correlated. Bruce (2006) asserts that people who work in an enjoyable and fun-filled workplace come to see their jobs as a place to fulfill many different needs, reinforcing their motivation to perform at a higher level. The author also suggests some guidelines to make the workplace pleasurable, such as laughing with people, lightening up, thinking with a sense of humor, adopting a fun and playful attitude, planning to have a good time every single day, and helping others see the lighter side of things. Fun at work makes a happier environment and motivates employees. When the employees feel stress, and tired and are not eager to continue their tasks, a laugh can make the environment different, and they become inspired to work again with pleasure.

\section{i) Team spirit among the workforce}

Team spirit unifies the employees and encourages them to work together. Smart corporate leaders attempt to build up team spirit among their people and lead them from the front. Chandler and Richardson (2005) explained that there is nothing more motivational than leading from the front. It hits harder and lasts longer than any other practice. Also, they added that it changes people more deeply and more 
completely than anything else we can do. Leading from the front creates team spirit. Ideal corporate leaders care about their workforce as well as the organization. They show their employees the practicality of the work. This action inspires employees and has a positive impact on them, and they become influenced to work together for the betterment of the organization. To build up team spirit among the workforce, corporate leaders should give the team a clearly defined organizational goal. It motivates the workforce in achieving the goal. Regarding team spirit, Henry Ford's word is mentionable here; "Coming together is a beginning, keeping together is progress, and working together is a success."

\section{j) Promotion in due time}

Employees should get promotion in due time since it is an important motivational factor. Promotion in the higher position makes an individual happier and satisfied. By this, an employee gets motivated and committed to do more something for the betterment of the organization. Consequently, he/she becomes more productive and efficient. Organizations ought to develop a well-built promotion policy for their workforce. This policy must be free from any biased and unfairness. During the promotion, there must have a free and fair selection process. Otherwise, it will create mismanagement in the organization and bring frustration to the employees.

\section{k) Leading with enthusiasm}

Enthusiasm is a crucial part of motivational factors. We know that nothing great was ever created without interest. It is a part of the character of a motivational leader. Corporate leaders must be enthusiastic first, and then their people will be energized accordingly. Chandler and Richardson (2005) assert that enthusiasm is contagious. People love to be around it. It makes them smile. When the manager is excited regarding his/her idea, everyone else will be excited. Ideal corporate leaders make their employees enthusiastic about doing their job cordially. In this regard, the top-level management ought to identify the different interests of individuals in an organization.

\section{I) Personal and organizational integrity}

Gandz et al. (2013) asserts that integrity is essentially about wholeness, completeness, and soundness of leadership character. It is most readily apparent in principles, such as honesty, authenticity, transparency, candor, and consistency, but it is also used to describe high moral standards. A corporate leader should be honest personally to lead and motivate his/her employees. Organizational integrity mostly depends on the personal integrity of all levels of individuals in the organization. If a manager is not honest, he/she has no morale to influence others, to be sincere. Corrupted managers cannot stop corruption in organizations. Transparency and accountability in all levels of management can ensure managerial integrity that motivates the workforce, to be honest and productive to achieve organizational goals.

\section{m) Organizational vision and goals}

Corporate leaders can influence their people to format an organizational vision and goals. Formatting vision and goals, corporate leaders show the guidelines to their people where they must go and what they should carry out first to achieve the goals. In this regard, Chandler and Richardson (2005) explain that without goals (the subsets of vision), the team will just fight fires, work through emotional upsets, and worry about the dysfunctional behavior of other people. If corporate leaders spend their time doing second things first, most goals will not be achieved. There should be made an action plan in the organization for successfully meeting the goals. Furthermore, organizational vision and goals make the human resources in meeting the challenges and coping with the changes in the corporate sector.

\section{n) Producing optimism among the workforce}

Optimism is the practice of focusing on opportunities and possibilities rather than complaints and regrets. Chandler and Richardson (2005) emphasize that pessimism is the most fundamental of all the mistakes managers can make. It is a position, a pose, taken by the manager of not being optimistic about the future of the organization and, therefore, the future of the team. Also, they added optimistic leaders acknowledge the downside of every situation, and then focus the majority of their thinking on the upside. The downside is always well known by the individuals of the organization. On the contrary, the upside is not constantly well known. Optimistic corporate leaders bring the upside to light so that employees can look at the bright future by doing their level best. Corporate executives must believe in a better tomorrow. It is corporate leaders' responsibility to hold hope, trust, and faith high for their workforce. These optimistic issues increase employees' self-confidence. Corporate leaders with a hopeful mentality can manage their people to do the best effectively and efficiently for the betterment of the organization as well as the stakeholders.

\section{o) Religious belief and values}

Religious belief stands on the spiritual aspects of religion, and also, religious values hold ethical principles based upon religion. Religious belief and values influence the workforce in an organization. A believer employee, who is aware of the consequences of his/her action, cannot be corrupted. If a human becomes spiritually motivated, he/she will maintain transparency in the workplace. Accordingly, this transparency will help the employee to increase his/her productivity. But in many cases, this motivational issue is neglected in organizations. Corporate leaders ought to ensure the spiritual environment in organizations so 
that the employees can maintain their religious beliefs and values properly since it makes sure honestytransparency and consequently increases efficiency and productivity.

\section{p) Training and development programs}

Gilmore (2009b) asserts that training and development activities are matters of concern for individuals, employers, and government. Furthermore, the author added that an educated and skilled workforce is essential for firm competitiveness, the effective functioning of the economy, the competitiveness and wealth of the nation, and the overall well-being of society. Mrudula (2006) highlights an effective training program results in motivation. It is a vital function for every organization. It helps in creating a sustainable win-win relationship between employee and employer and also facilitates employers in retaining the talented workforce. Werner and DeSimone (2012) defined human resource development as a set of systematic and planned activities designed by an organization to provide its members with the opportunities to learn the necessary skills to meet current and future job demands.

An organization can arrange two types of training programs for its human resources; on-the-job training and off-the-job training. Naturally, on-the-job training is prearranged, and it takes place at the trainee's natural workplace. In this training, the trainee learns by doing his/her job at the workplace under the supervision of respective senior executives and becomes familiar with his/her work environment and gains practical knowledge. In contrast, off-the-job training is held away from the workplace of the employee, and it provides a learning atmosphere away from instant work stresses. In such training programs, employees gain a working knowledge in a designed training session. This type of training will not be helpful, if not directly associated with actual organizational issues. Training and development program is a salient motivational factor that makes the workforce confident to be efficient and productive.

\section{q) Comfortable work environment}

The work environment is a broad term and means all the surroundings when working and comfortable work environment means that all the surroundings are favorable for someone in the workplace. Work environment directly relates to physical (physical resources) and psychological (how the work is organized and wellbeing of the workforce) aspects. The environment of the workplace should be comfortable and conducive for the workforce so that it can relieve their work stress and make the work enjoyable. If employees can work without mental stress, it will increase their productivity. The workforce ought to get supporting resources to accomplish their tasks smoothly. In this regard, if employees can work with all essential resources in their workplace, it will make them concentrated on their assignments. Happier employees become satisfied with their job. A comfortable work environment brings happiness to the workforce and motivates them to increase their efficiency and productivity.

\section{r) Resolving conflict}

Conflict resolution is one of the factors of employee motivation in increasing productivity because any kind of conflict decreases productivity. Some of the signs of workplace conflict are job insecurity, backbiting, low morality, negative attitudes, and performance when one's work is not appreciated (Mrudula, 2006). There is no one accepted definition of conflict in an organization, and it can be defined in several ways. Conflict takes place when two or more individuals or groups have differing interests, and they pursue these interests intensely. It can range from friendly competition to extreme violence (Carter, 2006). There are four types of conflicts at the workplace based on their scopes:

- Psychological conflict: This type of conflict occurs in the mind of an individual, and an individual's ideas, decisions, or actions don't match with the job. In this situation, the individual suffers from the dissatisfaction with his/her work and duties.

- Personal conflict: This conflict occurs between two individuals at the workplace and where two people don't just get along. In this regard, they try to defeat each other to attain goals.

- Group conflict: It happens between two linking groups in the organization, and they do not intend to collaborate with each other.

- Organizational conflict: This kind of conflict occurs between two competitive organizations in achieving their goals.

Any kind of workplace conflict increases absenteeism in an organization. It is common that where two or more people; or groups work together, conflicts may arise. If we want to resolve clash in the workplace, first of all, we have to identify the root cause of the conflict. In this regard, corporate leaders can consider five conflict modes; collaborating, accommodating, competing, avoiding, and compromising according to the Thomas-Kilmann (1974) model (Brahnam, Margavio, Hignite, Barrier, \& Chin, 2005):

- Accommodating: The goal of accommodating is to give up the conflict maintaining harmony. Accommodating occurs when one side is yielding another's point of view and obeying an order when one part doesn't want to. It reduces the gap between individuals and increases personal relationships.

- Avoiding: The goal of avoiding is to hold up. In this mode, one or both sides withdraw from the situation just to stay away from the bad situation. Avoiding 
makes the work environment calm and ensures concentration on the assigned tasks of individuals.

- Competing: It is an aggressive approach. In this mode, an individual tries to win and stands up for his/her position or rights. There is an option of a winloss struggle between individuals. It is appropriate if no future relationship is needed with another party, and resolution of dispute needs to secure maximum possible result now.

- Collaborating: Collaborating is an attempt made by one or both parties to satisfy the needs of both. With collaboration, both sides can be winners. It is appropriate where the future relationship of both parties is significant for achieving their goals. The goal of this mode is multiple participation. It tries to find out a win-win solution for both.

- Compromising: The goal of compromising is to find a middle ground. It happens when both parties gain and lose to resolve the conflict. In this resolution, each party is partially satisfied and partially dissatisfied. In compromising, relationships remain undamaged, and it may be acceptable to all.

There are constructive and destructive conflict management styles in organizations. Constructive approaches refer to mutual respect, cooperation, and protecting others. At this juncture, a person or group focuses on the others' needs and collective relationships. Accordingly, it resolves the conflict. On the contrary, destructive styles involve threat, manipulation, and coercion. In this case, individual focuses on one's need desired outcomes; it encourages conflict. Expert corporate leader or counselor can resolve the psychological conflict of an individual by proper counseling. Organizations should eradicate conflict so that individuals can concentrate properly on their assigned tasks.

\section{Vili. Conclusion}

Effective governance and motivational leadership are the two parts of an organization that significantly help to achieve organizational goals. Furthermore, they are change-makers and motivators of people in the organization. Corporate governance and managerial leadership can jointly employ numerous motivational factors to motivate the workforce in an organization. Motivated people become more efficient and productive and able to cope with the changes in a competitive corporate environment. Proper motivation can ensure more committed human resources that are crucial parts of the organization in increasing organizational productivity. A healthier organization is vital for making motivated workforce.

\section{References Références Referencias}

1. Bruce, A. (2006). How to motivate every employee: 24 proven tactics to spark productivity in the workplace. New York: McGraw-Hill.

2. Brahnam, S., Margavio, T., Hignite, M., Barrier, T., \& Chin, J. (2005). A gender-based categorization for conflict resolution. Journal of Management and Development, 24(3), 197-208. Retrieve from https://doi.org/10.1108/02621710510584026

3. Boxall, P. F., Purcell, J., \& Wright, P. M. (Eds.). (2007). The Oxford handbook of human resource management. Oxford University Press on Demand.

4. Chebolu, R. M. (2006). Employee empowerment: a workplace strategy for motivation. In E. Mrudula (Ed.), Employee motivation: an introduction (pp. 5766). Hyderabad, India: The ICFAI University Press.

5. Carter, G. L. (2006). How to manage conflict in the organization ( $2^{\text {nd }}$ Ed.). USA: American Management Association (AMA)

6. Chandler, S., \& Richardson, S. (2005). 100 ways to motivate others: how great leaders can produce insane results without driving people crazy. Petaling Jaya, Malaysia: Advantage Quest Publications.

7. Eerde, W. V. (2015). Motivation and reward systems. The Netherlands: University of Amsterdam. Retrieved from https://www.researchgate.net/pu blication/313993584_Motivation_and_Reward_Syste ms

8. Gilmore, S. (2009a). Introducing human resource management. In S. Gilmore \& S. Williams (Ed.), Human resource management (pp. 3-20). New York: Oxford University Press.

9. Gilmore, S. (2009b). Developing human resources. In S. Gilmore \& S. Williams (Ed.), Human resource management (pp. 117-138). New York: Oxford University Press.

10. Gandz, J., Crossan, M., Seijts, G., \& Reno, M. (2013). Leadership character and corporate governance. Ivey Business Journal. Issues: May/June. Retrieved fromhttps://iveybusinessjou rnal.com/publication/leadership-character-and-corp orate-governance/

11. Hill, L. A. (2003). Becoming a manager: how new managers master the challenges of leadership. Boston, USA: Harvard Business School Press.

12. Harunavamwe, M., \& Kanengoni, H. (2013). The impact of monetary and non-monetary rewards on motivation among lower level employees in selected retail shops. African Journal of Business Management, 7(38), 3929-3935. DOI: 10. 5897/AJBM2012.1381

13. Kotter, J. P. (1999). on what leaders really do (1 $1^{\text {st }}$ eBook ed.). Boston, USA: Harvard Business School Press. ISBN: 978-0-8758-4897-6.

14. Mrudula, E. (2006). Understanding employee motivation. In E. Mrudula (Ed.), Employee 
motivation: an introduction (pp. 3-15). Hyderabad, India: The ICFAI University Press.

15. Newell, H., \& Scarbrough, H. (Ed). (2002). Human resource management in context: a case study approach. New York: PALGRAVE.

16. Pilbeam, S. (2009). Rewarding people at work. In S. Gilmore \& S. Williams (Ed.), Human resource management (pp. 168-192). New York: Oxford University Press.

17. Robbins, S. P., \& Judge, T. A. (2011). Organizational Behavior. (14 ${ }^{\text {th }}$ ed.). New Jersey: Prentice Hall.

18. Smith, C. A., Organ, D. W., \& Near, J. P. (1983). Organizational citizenship behavior: its nature and antecedents. Indiana University Journal of Applied Psychology, 68(4), 653-663. Retrieved from http://130.18.86.27/faculty/warkentin/SecurityPapers /Merrill/SmithOrganNear1983_JAP_OCB.pdf

19. Tiller, S. R. (July, 2011). Effective business governance. Leadership and Management in Engineering, 11(3). Retrieved from https://doi.org/10.1061/(ASCE)LM.1943-5630.0000 128

20. Werner, J. M., \& De Simone, R. L. (2012). Human Resource Development ( $1^{\text {st }}$ ed.) Delhi, India: Cengage Learning India.

21. Weill, P., \& Ross, J. W. (2004). IT governance: How top performers manage it decision rights for superior results? Boston: Harvard Business School Press. Retrieved from https://www.researchgate.net/pub lication/236973378_IT_Governance_How_Top_Perfo rmers_Manage_IT_Decision_Rights_for_Superior_R esults 